\title{
ВЫЯВЛЯЕМОСТЬ ГЕСТАЦИОННОГО САХАРНОГО ДИАБЕТА СРЕДИ БЕРЕМЕННЫХ УЗБЕКСКОЙ ПОПУЛЯЦИИ
}

\author{
'Ибрагимова Н.Ш., ${ }^{2}$ Атаджанова М.М., ${ }^{2}$ Тожиева И.М.
}

'Благотворительная общественная организация больных сахарным диабетом «UМID» Ташкент, Узбекистан Республиканский Специализированный Научно-Практический Центр Эндокринологии Мз Руз, Ташкент, Узбекистан

Учитывая влияние гестационного сахарного диабета (ГСД) на высокую частоту осложнений беременности, родов и послеродового периода, а также его неблагоприятные отдаленные последствия, Благотворительное общественное объединение инвалидов и больных сахарным диабетом «УМИД» реализовало Международный проект «Стратегия профилактики и мониторинга ГСД в Узбекистане», полученный от Всемирного Фонда Диабета WDF (2017-2020 гг.) для решения проблемы ГСД в Узбекистане.

ЦЕЛЬ: впервые в Узбекистане изучить распространенность ГСД и определить доминирующие факторы риска среди беременных узбекской популяции.

МАТЕРИАЛЫ И МЕТОДЫ: в рамках реализации проекта в 8 пилотных регионах проведен универсальный скрининг на ГСД среди 2798 беременных на 16-30-й неделе беременности в возрасте 18-40 лет. Скрининг включал: заполнение карт обследования; антропометрию (рост, вес, индекс массы тела (ИМт)); измерение артериального давления; осмотр специалистов (эндокринолога, гинеколога, кардиолога); ультразвуковое исследование плода и электрокардиографию; исследование в венозной крови уровня глюкозы натощак и через 60 мин после нагрузки 75 г глюкозы. Диагноз устанавливался согласно критериям IADPSG (2010).

РЕзУЛЬтАТЫ: впервые проведенный скрининг среди 2798 беременных в 8 пилотных регионах Узбекистана выявил ГСД у 296 беременных, что составляет 10,6\%. Уровень гликемии натощак соответ-

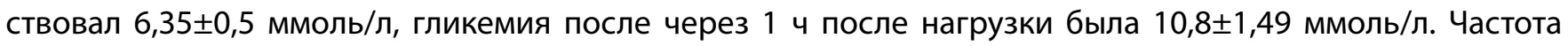
встречаемости ГСД в 8 пилотных регионах колебалась в различной степени. Так, наиболее высокое число беременных с ГСД выявлено в Ташкентской - 14,3\%, Сурхандарьинской - 13,1\% и Андижанской 12,9\% областях. Высокая распространенность ГСД, выявленная в данных областях, обусловлена частичным обследованием городского населения (до 30\%). В остальных регионах частота встречаемости ГСД составила: в Ферганской и Хорезмской областях - по 10,6\%, в Самаркандской области - 9,6\%, в Наманганской $-7,9 \%$ и в Кашкадарьинской области - 6,4\%. В данных регионах обследованы только сельские жительницы.

Проведен анализ факторов риска ГСД среди беременных узбекской популяции, который выявил: на первом месте возраст старше 30 лет у 89 женщин (30\%), на втором - ожирение (ИМТ >30 кг/м²) у 77 (26\%), избыточная масса тела (ИМТ 25-29,9 кг/м²) - у 73 (24,6\%), отягощенная наследственность по сахарному диабеты (СД) 2 типа - у 56 (18,9\%), и третьем - крупный плод - у 55 (18,6\%); из них 39 (13,1\%) женщин рожали от одного до трех детей весом более 4 кг и 16 (5,4\%) - детей весом более 5 кг. Другие факторы риска: прибавка в весе в анамнезе более 15 кг за период беременности - у 41 (13,8\%); выкидыши неясной этиологии - у 23 (7,7\%); неразвивающаяся беременность - у 18 (6,1\%); артериальная гипертензия - у 9 (2,3\%); преждевременные роды - у 6 (2\%); врожденные пороки развития - у $5(1,7 \%)$ и мертворождения в анамнезе - у 4 (1,3\%).

ВЫВОДЫ: впервые изученная частота встречаемости ГСД в Узбекистане составила 10,6\%. У беременных узбекской популяции выявлены превалирующие факторы риска ГСД: возраст старше 30 лет, ожирение, избыточная масса тела, отягощенная наследственность по СД 2 типа и наличие крупного плода в анамнезе. Высокая частота ГСД среди беременных в Узбекистане $(10,6 \%)$ свидетельствует о необходимости включения диагностики ГСД в стандарты обследования беременных женщин. 